\title{
Dimensions of Bullying Among Secondary School Students in Ekiti State, Nigeria
}

\author{
Mokuolu Bolade Olubunmi \\ Department of Psychology, Faculty of the Social Sciences, Ekiti State University, Ado-Ekiti, Nigeria
}

Email address:

bolade.mokuolu@eksu.edu.ng

\section{To cite this article:}

Mokuolu Bolade Olubunmi. Dimensions of Bullying Among Secondary School Students in Ekiti State, Nigeria. Psychology and Behavioral Sciences. Vol. 4, No. 5, 2015, pp. 190-193. doi: 10.11648/j.pbs.20150405.13

\begin{abstract}
Bullying has been considered a problem that has come to stay among students especially at secondary school level, and when the word bullying is mentioned, what comes to mind is physical aggression among boys. The study has been able to assess bullying from different dimensions by employing Multi-dimensional Peer-victimization scale (MPVS). 561 secondary school students drawn from three schools comprising of one boys only, one girls only and one mixed school consisting of boys and girls, making a total of 300 boys and 261 girls, all in Ekiti State, Nigeria were involved. The result of the study reveals that female students $($ Mean $=15.01)$ score significantly higher in bullying than male students $($ Mean $=12.21)$; in verbal victimization (mean Female $=4.32$, Male $=3.64$ ), attack on property (mean Female $=4.42$, Male $=3.52$ ), and social manipulation (mean Female $=4.01$, Male $=2.61$ ). There is no significant difference between male and female students in physical victimization.
\end{abstract}

Keywords: Bullying, Peer Victimization, Social Manipulation, Attack on Properties, Verbal Victimization

\section{Introduction}

Bullying is a tradition that has come to stay with students in secondary schools. It is so common that instead of seeing it as a threat. It is seeing as part of the characteristics of people at youthful stage. It is a social and interpersonal problem that involves the repeated, intentional use of aggression against a less powerful other (Whitney \& Smith, 1993). Bullying can be explained as aggressive behavior by an individual towards a less powerful person with the intent to hurt the person physically or emotionally and also to oppress the person. As common as bullying is, researchers has found that it has the potential to cause either physical or psychology harm to victim (Berthold \& Hoover, 2000; Carney \& Merrell 2001; Olweus 1993) most definition of bullying stress it as the repeated aggressive act that are intended to harm with and without provocation by the victim.

Bulling can take different forms, it can be physical aggression which may involve kicking, hitting, taking personal belonging, pushing, e. t. c., it can also be verbal which involve teasing maliciously, calling the victim names, being shouted at, being humiliated, threat, isolation e. t. c. and it can also be psychological, for example social exclusion, spreading of rumors, extortion, false gossip, mocking e. t. c. Ross (1998) outlined direct and indirect bulling. Direct is said to involve a great deal of physical aggression such as beating, biting, e.t.c., whereas indirect can be regarded as social aggression which include spreading gossip, refusing to socialize with the target, bullying others who wish to socialize with the target.

Students have been experiencing power struggles, embarrassment, fear, isolation, guilt, loss of friends. Such issues that follow a person into adulthood if they are not intervened have been found to be significant effect of bullying and emotional abuse on students. It has been concluded on the basis of longitudinal studies that repeated exposure to being bullied can and indeed often does undermined the health and wellbeing of vulnerable student (Egan, \& Perry 1998, Rigby 1996).

Social learning theory tries to explain that those who bully were bullied themselves, this suggests that bullying others are seen as the reward of being bullied, because this is retained in their mind, it serves as motivation and the behavior reproduces itself repeatedly. So, aggressive behavior (bullying) could be said to have been learned going by social learning theory. The different component of learning can be used to explain the reason for repeated bullying in school. Observational learning and reinforcement for example has demonstrated this as in the case of bobo doll experiment by Bandura and Walters (1963). The experiment demonstrated that children learn and imitate 
behavior they have observed in other people, as the children in the study learned violence by observing an adult acting violently towards a bobo doll. When the children were later allowed to play in a room with the bobo doll, they displayed the aggressive actions they have previously observed.

The group that children associate with in school also has an impact on whether he will become a bully or will be bullied, as social identity theory explains that the more strongly one identifies with a given group membership, the more likely one is to act on behalf of the group, which in turn enhance one's social identity. Studies have shown that bullying occurs mostly among children and adolescents in any setting like schools and workplace etc. (Olweus, 2003; Owoyemi \& Oyelere, 2010; Pelegrini, 1998). And bullying at schools has the tendency to affect academic, physical and mental wellbeing of the bullied and even the bullies because it makes the academic environment to be unsafe. This may in turn make the victims to have difficulty in concentrating on their school work, may also show signs of loneliness which may result in depression.

This study examines the dimensions of bullying among the secondary school students. It observes sex difference and the effect of school structure (single sex or mixed; boarding or day) on the dimensions of bullying. Bullying for the purpose of this study means exposure to negative actions repeatedly over time by one or more students, as measured by Multidimensional Peer Victimization scale, and it has four dimensions which include verbal victimization, social manipulation, attack on properties and physical manipulation.

\section{The Hypotheses Tested in the Study Includes}

There will be a significant effect of sex on the manifestation of bullying behavior among secondary school students.

School structure will significantly affect bullying behavior among the students

There will be a significant interaction effect of sex and school structure on bullying behavior among the students.

\section{Methods}

The research participants were 561 students drawn from three secondary schools in Ekiti State Nigeria. The three schools comprised of single-sex boys operating both boarding and day, single-sex girls operating only boarding and mixed schools comprising boys and girls with only boarding students. 200, 171 and 190 students were drawn from the three schools respectively with the average age of 13 years

Measures: "The Multidimensional peer victimization scale" (MPVS) developed by Mynard and Joseph (2000) was employed to measure Bullying. MPVS is a self report 16item scale designed to assess four types of peer victimization which are physical victimization, verbal victimization, social manipulation and attack on property scale; with internal consistency validity of $0.85,0.75,0.72$, and 0.73 respectively. The total score range from 0 to 32 and the subscale from 0 to 8. Higher score indicate greater level of victimization.

Procedure: the study was carried out during class after obtaining written permission from the school authorities. The students were randomly selected from each of the classes using systematic random sampling. With the help of the class teachers the sampling was done in proportion to the number of students in each level. The samples at each class level were gathered in a class, where they were given brief information on how to fill the questionnaire, and were given time to fill the questionnaire which were collected immediately they were through with it.

\section{Results}

The first hypothesis which states that there will be a significant effect of sex on the manifestation of bullying behavior among secondary school students was tested and the result is shown in table one.

Table 1. Independent t-test table showing the effect of sex on the manifestation of the dimensions of bullying.

\begin{tabular}{lllll}
\hline Variable & Sex & Mean & Std deviation & t \\
\hline \multirow{2}{*}{ Peer victimization } & Male & 12.21 & 6.88 & $-4.83 * *$ \\
& Female & 15.01 & 6.79 & \\
Verbal victimization & Male & 3.64 & 2.22 & $-3.52 * *$ \\
& Female & 4.32 & 2.36 & \\
Social manipulation & Male & 2.61 & 2.21 & $-7.01 * *$ \\
& Female & 4.01 & 2.49 & \\
Attack on property & Male & 3.52 & 2.41 & $-4.73 * *$ \\
Physical & Female & 4.42 & 2.03 & \\
victimization & Male & 2.33 & 2.27 & 0.26 \\
\hline
\end{tabular}

Significant at. $01 ; \mathrm{df}=559$ Male $\mathrm{N}=300 ;$ Female $\mathrm{N}=261$

Table 2a. One way ANOVA table showing the effect of school structure on bullying behavior among the students.

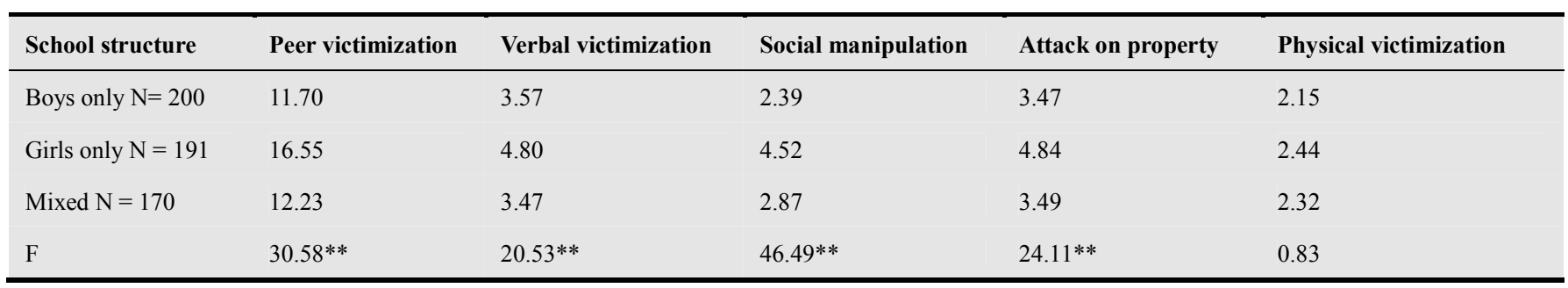

** Significant at. $01 ; \mathrm{df}=2,558$ 
Table 2b. Post hoc analysis showing the direction of differences in the mean scores of bullying behavior among the different school.

\begin{tabular}{llll}
\hline Variables & Boys/ Girls & Girls / Mixed & Boys / Mixed \\
\hline Peer victimization & $-4.85 * *$ & $4.31 * *$ & -0.53 \\
Verbal victimization & $-1.23^{* *}$ & $1.33^{* *}$ & 0.09 \\
Social manipulation & $-2.13 * *$ & $1.65 * *$ & -0.48 \\
Attack on properties & $-1.37 * *$ & $1.35 * *$ & -0.02 \\
\hline
\end{tabular}

** Significant at. 01 ;

The result in Table 1 shows significant sex difference in peer victimization and its dimensions except in the case of physical victimization.
The second hypothesis that school structure will significantly affect bullying behavior among secondary school students was tested and the result shown in table 2.

The structure of school has significant effect on the exhibition of peer victimization and the dimensions except physical victimization which seems to be the same in all the schools. The post hoc analysis also comparing students from boys only and girls only; girls only and mixed sex, shows that they are significantly different in all the dimensions of bullying, but the comparison of boys only and mixed sex has no significant difference in all the dimensions of bullying.

Table 3. Independent t-test table showing the difference in the dimensions of bullying between boys and girls from mixed schools; and also students from boys only and girls only.

\begin{tabular}{|c|c|c|c|c|c|c|c|}
\hline \multirow[b]{2}{*}{ Variables } & \multirow[b]{2}{*}{ Sex } & \multicolumn{3}{|c|}{ Mixed school } & \multicolumn{3}{|c|}{ Single sex Schools (boys only and gilrs only) } \\
\hline & & Mean & Std Deviation & $\mathbf{t}$ & Mean & Std Deviation & $\mathbf{t}$ \\
\hline \multirow{2}{*}{ Peer Victimization } & Male & 13.23 & 7.06 & $2.25 *$ & 11.70 & 6.74 & $-7.39 * *$ \\
\hline & Female & 10.81 & 6.65 & & 16.55 & 6.18 & \\
\hline \multirow{2}{*}{ Verbal victimization } & Male & 3.79 & 2.24 & $2.05 *$ & 3.57 & 2.21 & $-5.41 * *$ \\
\hline & Female & 3.02 & 2.55 & & 4.80 & 2.10 & \\
\hline \multirow{2}{*}{ Social manipulation } & Male & 3.06 & 2.23 & 1.27 & 2.39 & 2.17 & $-9.24 * *$ \\
\hline & Female & 2.61 & 2.27 & & 4.52 & 2.38 & \\
\hline \multirow{2}{*}{ Attack on property } & Male & 3.63 & 2.41 & 1.04 & 3.47 & 2.41 & $-6.17 * *$ \\
\hline & Female & 3.28 & 1.89 & & 4.84 & 1.92 & \\
\hline \multirow{2}{*}{ Physical Victimization } & Male & 2.68 & 2.46 & $2.40 *$ & 2.15 & 2.15 & 1.29 \\
\hline & Female & 1.81 & 2.08 & & 2.44 & 2.35 & \\
\hline
\end{tabular}

*significant at. 05

Mixed sex: Male $\mathrm{N}=100$, Female $\mathrm{N}=70$; same sex schools: Male N=200, Girls $\mathrm{N}=191$.

From the table, comparison of the girls only with the boys only from single sex schools also gives the same result but in the case of boys and girls from the same school (i.e. mixed sex), male students are significantly higher in peer victimization and its dimensions than the girls.

\section{Discussion}

The main objective of this study was to examine the dimensions of bullying that are common among students and the pattern among the boy and girls and the different school structures. It was hypothesized that sex and school structure will have significant main and joint effect on bullying behavior and the result actually confirmed this. This research focused on the different dimensions of bullying which include verbal victimization, social manipulation, attack on property and physical victimization. The result shows that girls are significantly higher in verbal victimization, social manipulation and attack on properties across the schools, while there is no significant difference between boys and girls in physical victimization.

Ordinarily when one hears the word bullying the mind goes to the male gender, thinking that aggression is a personality characteristic that should be expected among the males but the result of the research work shows that bullying is more prominent among the female students than the male except in the case of physical victimization. Peer victimization generally is significantly more rampant among girls in same sex school than boys in the case of mixed sex schools. This may be accounted for by the fact that when bullying is mentioned, what readily comes to mind is male gender and physical aggression such as being beaten, pushed, bitten, whereas physical victimization (aggression) is just an aspect of bullying. Going by the definition of bullying, it is any behavior that aims at hurting another person especially of a lower status. Hurting goes beyond being physically attacked, it involves psychological attack in terms of verbal, emotional or relational abuse. In comparing boys and girls in peer victimization generally, contrary to the general opinion, the research shows that girls are more involved in bullying than boys, bullying among girls are only subtle and indirect. The indirect bullying among girls include backbiting, lying against the victim in order to put the fellow into trouble, preventing others from relating with the victim.

Girls are more emotional and cherish relationship and intimacy than boys, so in order to victimize effectively, bullying targets the emotion, the social status and relationships. Bullying among girls which is indirect and more psychological has a long lasting effect on the victim than just physical bullying such as being beaten. An individual who was beaten up by the other fellow will get over it in a moment, but the indirect bullying among girls may end up in ostracism and social alienation which may have a long run effect on the social status and perception of self of the victims. Studies of aggression across culture differ but there is a uniformed report 
that boys are more involved in overt aggression while girls are often more involved in indirect or relational aggression than boys (Galen \& Underwood, 1997; Crick \& Rose 2000; Schaffer, Werner \& Crick 2002).

Considering gender relativism, overt aggressive behaviors are still socially acceptable as a stereotypical male role. When a male shows aggression in a state of provocation, and he is able to deal with the opponent, he earns respect from others, but not with girls, any girl who shows such overtly aggressive behavior may suffer social rejection and ridicule, but a girl will earn respect from others when she is able to use social manipulation to score some points.

The research also reveals that school structure has an impact on bullying activities. Comparing students from single sex and mixed schools, the result shows that students from girls-only schools are significantly higher in all the dimensions of bullying than students from boys-only and from mixed schools. Although boys from mixed school were reportedly more aggressive than the girls in the same school, also students that are in full boarding are involved significantly more in bullying than day students. This is in consonance with the report of Nansel, Overpeck, Pilla, Ruan Simon-Morton and Scheidt (2001) that girls are more likely to bully other girls, and boys tend to bully both boys and girls This may be due to the fact that the boarding is a closely knitted system and are made up of students from various backgrounds, they can easily influence one another's values through learning by imitation or reinforcement, the day students on the other hand have day to day interaction with their families which helps in a way to protect the value system imbibed by the family.

The result also reveals that physical victimization is not as rampant as earlier reported by researchers, as only $36.3 \%$ of the students scored above the average while $28.7 \%$ reported noninvolvement in physical victimization. Compared with other dimensions where less than $10 \%$ reported non-involvement. A study conducted by the Federal Ministry of Education (2007) reported physical violence accounted for $85 \%$.

Conclusion: There is a need to shift attention from boys to girls on the issue of bullying. The result of this research exonerates boys and implicates girls. The girls need reorientation and needs to be reminded of the caring nature that characterizes girls. Further research will need to focus on the impact bullying has on the self esteem and psychological well-being of girls compared with boys.

\section{References}

[1] Bandura A. \& Walters, R. (1963). Social learning and personality development. New York: Holt. Rinehart \& Winston.

[2] Berthold, K. A. \& Hoover, J. H. (2000). Correlates of bullying and victimization among intermediate students in Midwestern USA. Journal of School Psychology International, 21(1), 65-78.
[3] Carney, A. G. \& Merrell, K. W. (2001). Bullying in schools: perspectives on understanding and preventing an international problem. Journal of School Psychology International, 22(3), 364-382.

[4] Crick N. R. \& Rose A. J. (2000). Towards a gender-balanced approach to the study of social-emotional development: A look at relational aggression. In R. G. Geen \& E. Donnerstein (Eds), Human aggression: Theories, research, and implication for social policy (pp. 153-168). San Diego Academic Press.

[5] Egan, S. K. \& Perry, D. G. (1998). Does low self-regard invite victimization? Journal of Developmental Psychology, 34, 299309.

[6] Federal Ministry of Education (2007). The national strategic framework for violence free basic education in Nigeria. Abuja: Federal Ministry of Education.

[7] Galen B. R. \& Underwood M. K. (1997). Developmental psychology.33, 589-600.

[8] Mynard, H. and Joseph, S. (2000). Development of multidimensional peer-victimization scale. Aggressive Behaviour 26, 169-178.

[9] Nansel, T. R., Overpeck, M., Pilla, R. S., Ruan, W. J., SimonsMorton, B., \& Scheidt, P. (2001). Bullying Behaviors among U. S. Youth: Prevalence and Association with Psychosocial Adjustment. Journal of the American Medical Association, 285 (16) 2094-2100.

[10] Olweus, D. (1993). Victimization by peers: antecedents and long term outcomes. In K. H. Rubin \& J. B Asenddorf (Eds.), Social Withdrawal, Inhibition, and Shyness in childhood. Hillsdale, NJ: Lawrence Erlbaum.

[11] Olweus, D. (2003). Bullying at school, what we know and what we can do. Cambridge, Mass: Blackwell London. 145149.

[12] Owoyemi O. \& Oyelere, M. (2010). Workplace bullying: an undiagnosed social school students in Nigeria. International Education Journal, 2005, 6(5), 598-606.

[13] Pelegrini, A. D. (1998). Bullies and victims in school: A review and call for research. Journal of Applied Developmental Psychology 19, 15-176.

[14] Rigby k. (1996). Bullying in school and what to do about it. Melbourne: The Australian Council for Educational Research.

[15] Ross D. (2002). Bullying. In J Sandoval (Ed.), Handbook of crisis counseling, intervention, and prevention in the schools (electronic version) $2^{\text {nd }}$ ed., 105-135: Mahwah, NJ: I, Erlbaum Associates.

[16] Schafer, M., Werner, N. E., \& Crick, N. R. (2002). A comparison of two approaches to the study of negative peer treatment: General victimization and bully/victim problems among German school children. British Journal of Developmental Psychology 20, 281-306.

[17] Whitney I. \& Smith P. K., (1993). A survey of the nature and extent of bullying in junior/ middle and secondary schools. Journal on Educational Research 35, 3 - 25. 